\title{
Genetic Variation and Structure of native and introduced Casuarina equisetifolia (L. Johnson) Provenances
}

\author{
By G. H. Huang ${ }^{1)}$, C. L. Zhong ${ }^{1),{ }^{*}}$, X. H. Su ${ }^{2)}$, Y. Zhang ${ }^{1)}$, K. Pinyopusarerk ${ }^{3)}$, C. Franche ${ }^{4)}$ and D. Bogusz ${ }^{4)}$
}

(Received 12 $2^{\text {th }}$ March 2008)

\begin{abstract}
Casuarina equisetifolia is an important tree species in tropical/subtropical zones of Asia, the Pacific and Africa. In this study, 220 individuals from seven native provenances and eleven introduced provenances of $C$. equisetifolia were analyzed to assess the genetic variation and structure using amplified fragment length polymorphism (AFLP) markers. A total of 465 bands were obtained by eight primer pairs, among which 153 were polymorphic. The mean NEI's gene diversity $H=0.2113$ calculated for 18 provenances and the total gene diversity $H_{T}=0.4065$ calculated for native provenances suggested abundant variation within provenances and species. High genetic divergence coefficient $\left(G_{S T}=\right.$ $0.4737)$ and low gene flow $\left(N_{m}=0.5555\right)$ detected among native provenances suggesting high differentiation of C. equisetifolia. An AMOVA analysis for native provenances revealed a high proportion $(46.07 \%)$ of the total
\end{abstract}

1) Research Institute of Tropical Forestry, CAF, Guangzhou 510520, P. R. China.

2) Research Institute of forestry, CAF, Beijing 100091, P. R. China.

3) CSIRO/Ensis, PO Box E4008, Kingston, ACT 2604, Australia.

4) Rhisogenèse Lab., Institut de Recherche pour le Développement, 911 avenue Agropolis, BP 64501, 34394 Montpellier cedex 5, France.

*) Corresponding author: Tel.: +86-20-87030939. Fax: +86-2087031622. E-Mail: zcl@ritf.ac.cn genetic variation distributed among provenances. The UPGMA clustering $(r=0.8028)$ and the Mantel test $(r=$ 0.0716 ) for native provenances showed there was no correlation among genetic relationships and geographical distribution. The genetic information provided important implications for the future conservation and breeding programs of $C$. equisetifolia.

Key words: Casuarina equisetifolia, AFLP markers, genetic variation, genetic structure, native range, introduced range.

\section{Introduction}

Casuarina equisetifolia (L. Johnson) has two subspecies: subsp. incana and subsp. equisetifolia (MIDGLEY et al., 1983; WILsON et al., 1989). The former occurs exclusively along the coast of Queensland and northern New South Wales of Australia and in Vanuatu. The latter has a wide native range, occurs on tropical and subtropical zones of Asia, the Pacific and Africa from throughout Malaysia to northern Australia, Melanesia, and Polynesia (Figure 1). As a fast-growing and nitrogen fixing tree of social, economic and environmental importance, it is commonly used in agroforestry systems, for soil stabilization, reclamation work, in coastal protection and rehabilitation. Though a littoral species in natural habitats it is well adapted to inland area, and has been introduced into southern China, India, East and West Africa, the United States of America, the

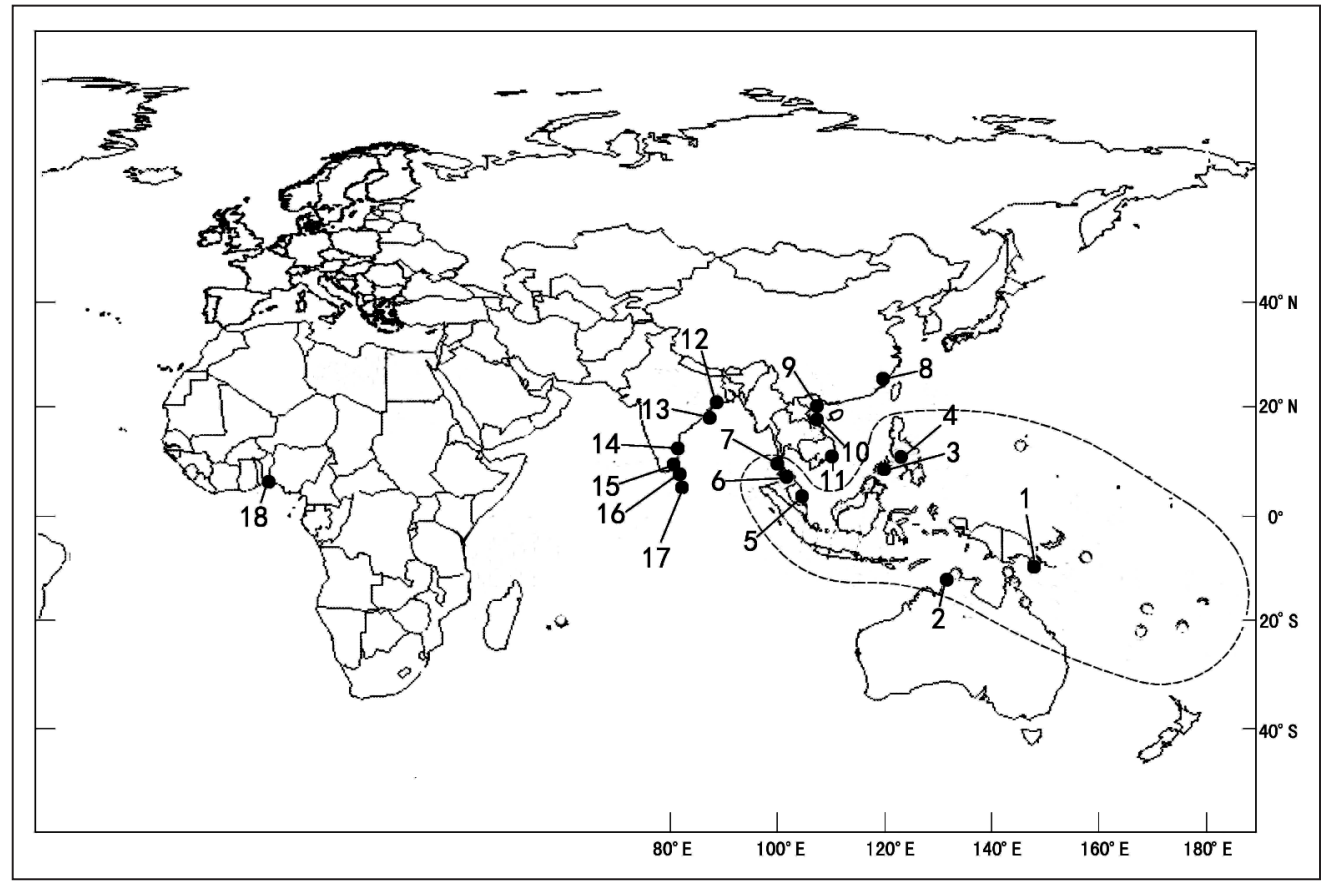

Figure 1. - The geographical distribution of 18 Casuarina equisetifolia provenances, within line is the native range of Casuarina equisetifolia ssp. equisetifolia. 
Caribbean, Vietnam, and some Middle East countries for more than a century. The provenances of $C$. equisetifolia exhibit significant of variation for growth characteristics, and grow on a variety of sites with very different annual precipitation and climatic conditions. Marked variation in growth and branching habit between different provenances, as well as individual trees within provenances, has been observed (PINYOPUSARERK and HOUSE, 1993; PINYOPUSARERK and WiLliAMs, 2000). However very little information is correctly available on the genetic variation of this species based on molecular technique despite its ecological and economic importance.

Information on the magnitude and structure of genetic variation within a species is an integral part of conservation and improvement of genetic resources. Amplified fragment length polymorphism (AFLP), which can be used to analyze large numbers of loci distributed throughout the genome, have proven a powerful tool in the assessment of genetic variation both within and among plant provenances without detailed prior knowledge of DNA sequences (Vos et al., 1995; BRown et al., 1990; JONEs et al., 1998). AFLP markers have been successfully used for analyzing genetic variation and genetic structure (BARRETT et al., 1998; JANSSEN et al., 1996; Xue et al., 2005; STEFENON et al., 2006).

The main goal in this study is to survey the levels and patterns of genetic variation of the provenances of C. equisetifolia using AFLP markers, and the genetic differentiation and genetic relationships among provenances were analyzed at the same time. Furthermore, we can compare the genetic diversity among native and introduced provenances. This work will provide valuable information for further genetic conservation and breeding program in C. equisetifolia.

\section{Materials and Methods}

\section{Plant materials and DNA extraction}

A total of 220 plants belong to 18 provenances were collected from an international provenance trial garden of $C$. equisetifolia subsp. equisetifolia established at
Zhangzhou in Fujian province of China. Some introduced provenances were included in the samples because we want to know the variation and the genetic information are needed for future management of these provenances since they have been identified as potential useful provenances in the south of China (ZHONG et al., 2001). The provenances in the introduced range are the result of provenance trail plantations. The geographic and ecological parameters of provenances are shown in Figure 1 and Table 1. Genomic DNA of each trees were extracted from fresh branchlets using a modified CTAB extraction (DoYLE, 1991). DNA concentrations were estimated and standardised against known concentrations of lambda DNA on $1 \%$ agarose gels.

\section{AFLP analysis}

AFLP analysis was carried out by the method of Vos et al. (1995) with some modifications. Approximately $300 \mathrm{ng}$ of total genomic DNA per samples were digested with EcoRI and MseI and then ligated with EcoRI adaptor and MseI adaptor. Including 64 primer combinations with three selective bases were screened in a preliminary test, eight primer (Table 2) combinations found to give good amplifications were selected for further study. Pre-amplifications were performed in a total volume of $20 \mu \mathrm{l}$ containing $2 \mu \mathrm{l}$ of ligation mixture, running on GeneAmp PCR 9700 using the following temperature conditions: denaturation at $94^{\circ} \mathrm{C}$ for $3 \mathrm{~min}, 30$ cycles of denaturation at $94^{\circ} \mathrm{C}$ for $30 \mathrm{~s}$, followed by annealing at $56^{\circ} \mathrm{C}$ for $30 \mathrm{~s}$, ending with extension at $72^{\circ} \mathrm{C}$ for $60 \mathrm{~s}$, a final step at $72^{\circ} \mathrm{C}$ for $5 \mathrm{~min}$. Selective amplifications were performed in a $20 \mu \mathrm{l}$ volume containing $4 \mu \mathrm{l}$ of preamplification products (diluted 50 times in TE). Amplifications were performed using the following temperature conditions: one cycle of denaturation at $94^{\circ} \mathrm{C}$ for $30 \mathrm{~s}$, followed by annealing at $65^{\circ} \mathrm{C}$ for $30 \mathrm{~s}$, ending with extension at $72^{\circ} \mathrm{C}$ for $60 \mathrm{~s}$, followed by 12 cycles under the conditions listed above, except for a $0.7^{\circ} \mathrm{C}$ lower annealing temperature for each cycle, and finally 30 cycles of $94^{\circ} \mathrm{C}$ for $30 \mathrm{~s}, 56^{\circ} \mathrm{C}$ for $30 \mathrm{~s}, 72^{\circ} \mathrm{C}$ for $60 \mathrm{~s}$. Following the selective amplification, the reaction products were mixed with an equal volume of loading buffer $(98 \%$ formamide, $10 \mathrm{mM}$ EDTA, $0.1 \%$ xylene cyanol, and $0.1 \%$

Table 1. - The information of 18 provenances of Casuarina equisetifolia ssp. equisetifolia investigated for AFLP variation.

\begin{tabular}{|c|c|c|c|c|c|c|c|}
\hline Pro. No. & CSIRO Seedlot No. & Provenance name & Country & Sample size & Latitude & Longitude & Altitude (m) \\
\hline \multicolumn{8}{|c|}{ Native provenances } \\
\hline 1 & 18153 & Ela Beach & Papua New Guinea & 15 & $09^{\circ} 05^{\prime} \mathrm{S}$ & $148^{\circ} 17^{\prime} \mathrm{E}$ & 10 \\
\hline 2 & 18008 & Darwin, Northern Territory & Australia & 10 & $12^{\circ} 25^{\prime} \mathrm{S}$ & $130^{\circ} 50^{\prime} \mathrm{E}$ & 20 \\
\hline 3 & 18357 & Narra, Palawan & Philippines & 10 & $09^{\circ} 19^{\prime} \mathrm{N}$ & $118^{\circ} 29^{\prime} \mathrm{E}$ & 10 \\
\hline 4 & 18154 & Aklan, Panay Island & Philippines & 10 & $11^{\circ} 31^{\prime} \mathrm{N}$ & $122^{\circ} 30^{\prime} \mathrm{E}$ & 30 \\
\hline 5 & 18348 & Kuantan, Pehang & Malaysia & 15 & $06^{\circ} 30^{\prime} \mathrm{S}$ & $99^{\circ} 45^{\prime} \mathrm{E}$ & 30 \\
\hline 6 & 18298 & Had Chao Mai, Trang & Thailand & 10 & $07^{\circ} 33^{\prime} \mathrm{N}$ & $100^{\circ} 37^{\prime} \mathrm{E}$ & 2 \\
\hline 7 & 18297 & Ban Kam Phuam,Ranong & Thailand & 15 & $09^{\circ} 21^{\prime} \mathrm{N}$ & $98^{\circ} 27^{\prime} \mathrm{E}$ & 10 \\
\hline \multicolumn{8}{|c|}{ Introduced provenances } \\
\hline 8 & Local & Dongshan, Fujian & China & 12 & $23^{\circ} 40^{\prime} \mathrm{N}$ & $117^{\circ} 28^{\prime} \mathrm{E}$ & 4 \\
\hline 9 & 18128 & Non Nuoc & Vietnam & 10 & $16^{\circ} 06^{\prime} \mathrm{N}$ & $106^{\circ} 20^{\prime} \mathrm{E}$ & 2 \\
\hline 10 & 18086 & Hai Thinh, Ha Nam Ninh & Vietnam & 13 & $20^{\circ} 22^{\prime} \mathrm{N}$ & $106^{\circ} 21^{\prime} \mathrm{E}$ & 1 \\
\hline 11 & 18152 & Ninh Chu,Ninh Thuan & Vietnam & 10 & $11^{\circ} 33^{\prime} \mathrm{N}$ & $108^{\circ} 59^{\prime} \mathrm{E}$ & 2 \\
\hline 12 & 18015 & Chandipur, Balasore, Orissa & India & 15 & $21^{\circ} 30^{\prime} \mathrm{N}$ & $86^{\circ} 54^{\prime} \mathrm{E}$ & 2 \\
\hline 13 & 18014 & Balukhanda, Orissa & India & 15 & $19^{\circ} 50^{\prime} \mathrm{N}$ & $85^{\circ} 53 \mathrm{E}$ & 10 \\
\hline 14 & 18120 & Chengai Anna, Tamil Nadu & India & 10 & $12^{\circ} 36^{\prime} \mathrm{N}$ & $79^{\circ} 48^{\prime} \mathrm{E}$ & 50 \\
\hline 15 & 18119 & Rameswaram, Tamil Nadu & India & 10 & $09^{\circ} 15^{\prime} \mathrm{N}$ & $79^{\circ} 20^{\prime} \mathrm{E}$ & 5 \\
\hline 16 & 18288 & Madagama & Sri Lanka & 15 & $08^{\circ} 06^{\prime} \mathrm{S}$ & $80^{\circ} 15^{\prime} \mathrm{E}$ & 80 \\
\hline 17 & 18287 & Hambantota & Sri Lanka & 10 & $06^{\circ} 08^{\prime} \mathrm{N}$ & $81^{\circ} 07^{\prime} \mathrm{E}$ & 16 \\
\hline 18 & 18355 & Cotonou & Benin & 15 & $06^{\circ} 23^{\prime} \mathrm{S}$ & $02^{\circ} 13^{\prime} \mathrm{E}$ & 8 \\
\hline
\end{tabular}


Table 2. - Number of fragments, number of polymorphic fragments, percentage of polymorphic fragments, and size of fragments for each primer pair used for AFLP analysis on Casuarina equisetifolia.

\begin{tabular}{ccccc}
\hline Primer pairs & Number of fragments & Number of polymorphic fragments & Percentage of polymorphic fragments & Size of fragments (bp) \\
\hline M-CAC/E-ACT & 45 & 19 & $42.22 \%$ & $75-600$ \\
M-CTA/E-AAG & 80 & 24 & $30 \%$ & $50-620$ \\
M-CTA/E-ACA & 65 & 23 & $35.38 \%$ & $115-820$ \\
M-CTC/E-AAC & 60 & 25 & $41.67 \%$ & $40-530$ \\
M-CTC/E-ACT & 50 & 20 & $40 \%$ & $40-375$ \\
M-CTG/E-AAG & 48 & 22 & $45.83 \%$ & $100-400$ \\
M-CTT/E-ACC & 64 & 9 & $14.06 \%$ & $40-680$ \\
M-CTT/E-AGC & 53 & 11 & $20.75 \%$ & $102-410$ \\
Total & 465 & 153 & $32.90 \%$ & \\
Mean & 58.13 & 19.13 & & \\
\hline
\end{tabular}

bromophenol blue). The mixtures were denatured for 5 min at $94^{\circ} \mathrm{C}$ then directly placed on ice. About $6 \mu \mathrm{l}$ of the mixtures were run in $6 \%(\mathrm{v} / \mathrm{v})$ polyacrylamide gels with a DNA sequencer. The gels were silver stained using the protocol published by STREIFF et al. (1998).

\section{Genetic analysis}

Each AFLP band of unambiguous pattern was given a score of 1 for presence or 0 for absence across all the polymorphic loci to create a binary matrix. POPGENE, version 1.31 (YEH et al., 1999) was used to calculate genetic parameters within the 18 sampled provenances, including the number of polymorphic loci $(N P)$, percentage of polymorphic loci $(P)$, observed number of alleles per locus $\left(N_{a}\right)$, effective number of alleles per locus $\left(N_{e}\right)$, gene diversity $(H)$ (NEI, 1973), Shannon's information index (I) (Lewontin, 1972). The total gene diversity $\left(H_{T}\right)$ within species and within provenances $\left(H_{S}\right)$, differentiation coefficient $\left(G_{S T}\right)$ and gene flow $\left(N_{m}\right)$ were calculated only for native provenances assuming Hardy-Weinberg equilibrium. The unbiased measure of genetic identity (GID) and genetic distance (GD) among native provenances was calculated using NEI's (1978), and the genetic distance matrix was used to construct dendrogram using unweighted pair group method (UPGMA) of SHAN in NTSYS software (ROHLF, 1994). In addition, a
Mantel test among genetic distances and geographic distances among native provenances was carried out by TFPGA 1.3 (MANTEL, 1967). The binary matrix of native provenances was used to generated a distance matrix with the AMOVA-PREP version 1.01 (MILLER, 1998) and the resulting distance matrix was subjected to an analysis of molecular variance (AMOVA) using WINAMOVA version 1.55 (STEWART and EXCOFFIER, 1996). The hierarchical analysis of the genetic variation partitioned among regions, as well as among provenances within regions was not carried out for some regions only have one or two provenances.

\section{Results}

\section{Genetic variation within native and introduced} provenances

The amplified results by each primer pair were shown in Table 2. Eight primer pairs revealed a total of 465 DNA fragments ranging from $40 \mathrm{bp}$ to $820 \mathrm{bp}$, among which $153(32.90 \%)$ of these bands were polymorphic loci either among or within provenances. Primer pairs were significantly different in their capacity to detect polymorphisms.

The genetic parameters for each of 18 C. equisetifolia provenances summarized in Table 3 indicated a tenden-

Table 3. - Genetic variation parameters of Casuarina equisetifolia provenances detected by AFLP markers. The mean values were calculated across provenances. $N P$, number of polymorphic loci; $P$, percentage of polymorphic loci; $N$ a, observed number of alleles per locus; $N$ e, effective number of alleles per locus; $H$, NeI's gene diversity; $I$, Shannon's information index.

\begin{tabular}{|c|c|c|c|c|c|c|}
\hline Pro. No. & $N P$ & $P$ & $\mathrm{Na}$ & $\mathrm{Ne}$ & $H$ & $I$ \\
\hline \multicolumn{7}{|c|}{ Native provenances } \\
\hline 1 & 117 & 76.47 & 1.7647 & 1.4569 & 0.2669 & 0.3990 \\
\hline 2 & 62 & 40.52 & 1.4052 & 1.2651 & 0.1533 & 0.2263 \\
\hline 3 & 87 & 56.86 & 1.5686 & 1.3701 & 0.2125 & 0.3140 \\
\hline 4 & 91 & 59.48 & 1.5948 & 1.4481 & 0.2466 & 0.3568 \\
\hline 5 & 87 & 56.86 & 1.5686 & 1.4328 & 0.2369 & 0.3411 \\
\hline 6 & 72 & 47.06 & 1.4706 & 1.3066 & 0.1737 & 0.2561 \\
\hline 7 & 104 & 67.97 & 1.6797 & 1.3515 & 0.2077 & 0.3175 \\
\hline \multicolumn{7}{|c|}{$\begin{array}{l}\text { Introduced provenances } \\
\text { (plantations) }\end{array}$} \\
\hline 8 & 20 & 13.07 & 1.1307 & 1.0817 & 0.0472 & 0.0701 \\
\hline 9 & 85 & 55.56 & 1.5556 & 1.4030 & 0.2248 & 0.3266 \\
\hline 10 & 92 & 60.13 & 1.6013 & 1.3307 & 0.1972 & 0.2986 \\
\hline 11 & 91 & 59.48 & 1.5948 & 1.4258 & 0.2359 & 0.3430 \\
\hline 12 & 99 & 64.71 & 1.6471 & 1.4026 & 0.2328 & 0.3458 \\
\hline 13 & 105 & 68.63 & 1.6863 & 1.5186 & 0.2854 & 0.4121 \\
\hline 14 & 81 & 52.94 & 1.5294 & 1.3909 & 0.2186 & 0.3173 \\
\hline 15 & 80 & 52.29 & 1.5229 & 1.3261 & 0.1871 & 0.2774 \\
\hline 16 & 93 & 60.78 & 1.6078 & 1.4113 & 0.2355 & 0.3460 \\
\hline 17 & 97 & 63.40 & 1.6340 & 1.4316 & 0.2457 & 0.3609 \\
\hline 18 & 78 & 50.89 & 1.5098 & 1.3475 & 0.1963 & 0.2878 \\
\hline Mean & 85.61 & 55.95 & 1.5596 & 1.3723 & 0.2113 & 0.3109 \\
\hline
\end{tabular}


Table 4. - Analysis of molecular variance (AMOVA) for seven natural provenances of Casuarina equisetifolia. d.f., Degrees of freedom; SSD, Sum of squares; MSD, Mean squared deviation; \% Total variance, the percentage of the total variance.

\begin{tabular}{ccccccc}
\hline Source of variation & d. f. & SSD & MSD & Variance component & \% Total variance & P value \\
\hline Among provenances & 6 & 1175.8804 & 195.980 & 14.814 & $46.07 \%$ & $<0.0002$ \\
Within provenances & 78 & 1352.5667 & 17.341 & 17.340 & $53.93 \%$ & $<0.0002$ \\
\hline
\end{tabular}

Table 5. - NEI's (1978) unbiase measures of genetic identity (above diagonal) and genetic distance (below diagonal) for seven natural provenances Casuarina equisetifolia.

\begin{tabular}{|c|c|c|c|c|c|c|c|}
\hline Pro. No. & 1 & 2 & 3 & 4 & 5 & 6 & 7 \\
\hline 1 & $* * * *$ & 0.6606 & 0.7192 & 0.7355 & 0.7288 & 0.6991 & 0.7747 \\
\hline 2 & 0.4146 & $* * * *$ & 0.7096 & 0.6848 & 0.7538 & 0.6948 & 0.6824 \\
\hline 3 & 0.3296 & 0.3430 & $* * * *$ & 0.7077 & 0.8157 & 0.7949 & 0.7462 \\
\hline 4 & 0.3072 & 0.3786 & 0.3457 & 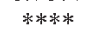 & 0.7019 & 0.6753 & 0.7112 \\
\hline 5 & 0.3164 & 0.2826 & 0.2038 & 0.3540 & $* * * *$ & 0.7472 & 0.6967 \\
\hline 6 & 0.3580 & 0.3641 & 0.2295 & 0.3926 & 0.2914 & $* * * *$ & 0.7538 \\
\hline 7 & 0.2553 & 0.3821 & 0.2927 & 0.3408 & 0.3614 & 0.2827 & 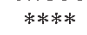 \\
\hline
\end{tabular}

cy for genetic variation of the Ela Beach native provenance in Papua New Guinea and Balukhanda, Orissa introduced provenance in India were higher than other provenances. The former was highest in number of polymorphic loci $(N P)$ 117, percentage of polymorphic loci $(P)$ $76.47 \%$ and observed number of alleles per locus $\left(N_{a}\right)$ 1.7647. The latter was highest in effective number of alleles per locus $\left(N_{e}\right)$, gene diversity $(H)$ and Shannon information index $(I)$ 1.5186, 0.2854 and 0.4121 , respectively. The Dongshan, Fujian provenance of China was lowest in all of the values, there were $N P=20$, $P=13.07 \%, N_{a}=1.1307, N_{e}=1.0817, H=0.0472$ and $I=0.0701$, respectively. The mean gene diversity was 0.2113 and Shannon information index was 0.3109 .

\section{Genetic structure among native provenances}

The POPGENE analyses for native provenances showed an abundant diversity $\left(H_{T}=0.4065 \pm 0.0128\right)$ at the species level, partitioning which $H_{S}=0.2139 \pm$ 0.0093 distributed within provenances and the rest among provenances. A high coefficient of genetic differentiation $G_{S T}=0.4737$ and low gene flow $N_{m}=0.5555$ $\left[N_{m}=0.5\left(1-G_{S T}\right) / G_{S T}\right]$ indicated the genetic divergence among $C$. equisetifolia provenances was substantial. An analysis of molecular variation (AMOVA) with 5000 permutations showed variance component $46.07 \%$ among

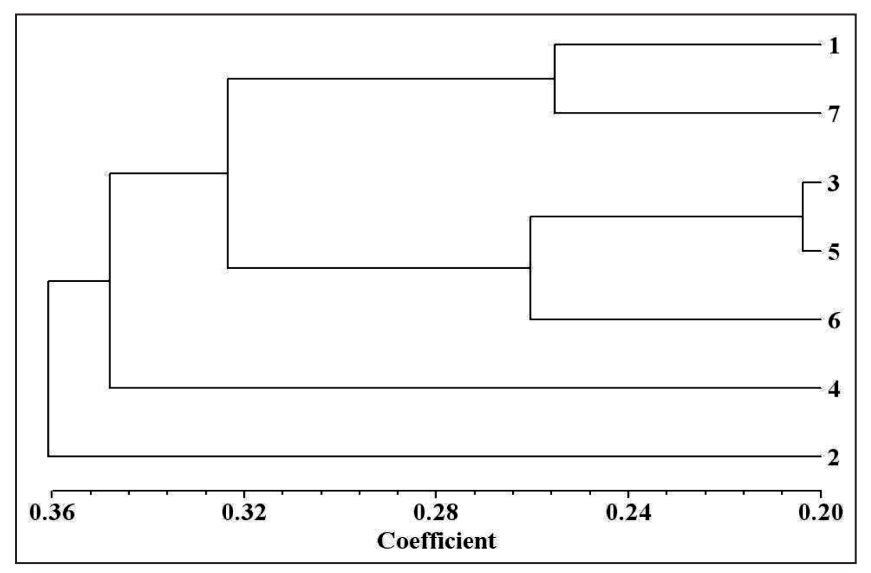

Figure 2. - Dendrogram generated by UPGMA clustering for seven native provenances of Casuarina equisetifolia, based on the NEI's (1978) genetic distances. provenances and $53.93 \%$ within provenances (Table 4), both were highly significant $(p<0.0002)$.

\section{Relationships among native provenances}

Genetic identity and genetic distances for each pair of native provenances were calculated and shown in Table 5. The genetic distances ranged from 0.2038 (between provenance 3 and provenance 5) to 0.4146 (between provenance 1 and provenance 2). The UPGMA cluster analysis based on NEI's (1978) unbiased genetic distances was performed to further show the genetic relationships among provenances (Figure 2). The cophenetic correlation coefficient of this cluster analysis was $r=0.8028(p=0.9994)$. Four groupings could be recognized from the dendrogram: the first group consisted of provenances 1 and 7 while the second group comprised provenance 3,5 and 6 . The provenance 4 and provenance 2 were segregated in third group and fourth group, respectively. A Mantel test with 1000 random permutations revealed no correlation between pair-wise genetic distances and geographical distances among provenances (correlation coefficient of $r=0.0716$, $\mathrm{p}=0.05)$.

\section{Discussion}

This study revealed that there was a large amount of genetic variation at provenance level and at species level of $C$. equisetifolia except the local Dongshan, Fujian provenance had extraordinarily low level variation. The mean gene diversity $(0.2113)$ was higher than HO (2002) result of 12 C. equisetifolia provenances (0.1473) assessed by RAPD, this may be account by the different provenances used in the two studies and the more gene loci can be detected by AFLP markers. The average Shannon's information index (0.3109) and the total gene diversity $(0.4065)$ were also higher than many other plants such as Picea asperata (0.227 and 0.237, respectively, XUE et al., 2005) based on AFLP.

The present result showed genetic variation among provenances $(46.07 \%)$ was a little higher than $\mathrm{HO}$ $(39.28 \%, 2002)$ result of 12 C. equisetifolia provenances based on RAPD markers, however, the same tendency of high proportion of total variation among provenances 
has been tested by the two different makers. Such results are in contrast with expectations for woody, perennial, predominantly outcrossed species, which maintain most variations within provenances (HAMRICK, 1990). However, this may be due to the low sample size in the study. High variation among provenances was also found in another tropical tree Tectona grandis (43\%, SHRESTHA et al., 2005) by AFLP. Even more variations among provenances have been detected in Syringa oblate, (51.53\%, MING and GU, 2006), Moringa oleifera Lam. (59\%, MULUVI et al., 1999) and Euterpe edulis Mart. (57\%, CARDoso et al., 2000) based on AFLP. The presence of such a high genetic variation among provenances could be attributed to the features of the wide distribution range of this species and the habitats where the sampled provenances occur. Its wide distribution is scattered through many islands, and therefore geographical isolation may occur. High degree of differentiation (0.4737) among provenances suggests that they have probably undergone random changes in genetic composition in response to prevalent environment conditions with limited gene flow (0.5555) between provenances. According to WRIGHT (1969), the critical value for $N_{m}$ is 0.5 . When $N_{m}$ value is below 1 , it means that provenances began to differentiate due to genetic drift. $N_{m}$ value below 0.5 indicates that populations will diverge extensively as a result of drift (MCDERMOTT and MCDONALD, 1993). Overall, the calculated gene flow $\left(N_{m}\right)$ indicates that the provenances were in the process of differentiation due to genetic drift.

It is interesting to find out that Balukhanda, Orissa introduced provenance was highest in genetic variation, reflecting the important implications on the introductions into this site. Multiple seed sources could have been collected to establish this plantation. Similarly, presumption that introduced provenances may have been derived from multiple seed sources can be seen from the higher variation (two Orissa provenance in India, two Sri Lanka provenances) than some native provenances. Although some of the introduced provenances existed abundant variation and could be used in the planting programs and breeding programs, the really problem is that there were no records of the origins of the seed which was first introduced to these places. Sampling of provenances in the native range must be much denser than presently undertaken with high resolution markers (such as AFLP markers) are likely to yield better results over the identities of the originating native provenances. In addition, chloroplast DNA pattern across the native range of the species might also enable increased resolution among the introduced provenances.

In general, if native provenances originated from the same hypothetical ancestors and underwent stable evolution, geographically close provenances should show the closest genetic relationships. However, the present result showed there was no distinct pattern of genetic distances correlated with geographic distances. This was consistent with YANG (1995) result that the variation of seed weight and seedling growth among provenances of C. equisetifolia was not continuous. However, the limited number of native provenances in this study may be another factor on the discordance. Introduced provenances were not included in the analysis for these provenances were only one or two generations removed from their wild provenances and were not in HardyWeinberg equilibrium. In fact, many of the clusters in the dendrogram had very low relation values (XUE et al., 2005; EREN KANDEDMIR et al., 2004; LI and XIA, 2005; HoNG et al., 2004; ZENG et al., 2003), suggesting that the clusters could be refined if more provenances and markers are included in future studies.

This work provides a deep insight into the genetic variation and genetic structure of $C$. equisetifolia, and supplies fundamental genetic information for conservation and breeding program of this species. Conservation programs dealing with native provenances of $C$. equisetifolia must take into account that most of the variation was distributed within provenance $(53.93 \%)$. Conservations of more family within a provenance could get important variation. Low intensity phenotypic selections within provenances are appropriate strategy to exploit the intra-provenance variation, offering a potential for selection of genetic material for tree improvement programs. On the other hand, high proportion of the total variation $(46.07 \%)$ and extensive genetic differentiation (0.4737) among provenances suggesting each provenance should be included in the conservation program because they possess partially unique genetic characteristics. In such a situation loss any provenance could result in an important loss of variation of the species. Preservation plots earmarked within natural forests can be considered as in situ conservation stands. They can be expected to retain much of the original variation as a result of better protection than other areas. Some introduced provenances (Balukhanda, Orissa in India and Hambantota in Sri Lanka) can also be considered in conservation and breeding program in the south of china for these provenances possesses substantial genetic variation. In this circumstance, the results of provenances trials are expected to be useful in the selection of a suitable provenance for a particular environment.

Superior trees assembled in germplasm banks is the only source of ex situ conservation for C. equisetifolia. Clonal seed orchards have a good collection for static conservation. However, they represent only a fraction of total genetic variation present within the species. Seedling seed orchards can serve as dynamic ex situ conservation stands with sufficiently broad genetic base for a long breeding and conservation program. An appropriate number of superior plants (It was collected 30-50 in China) of each provenances should be considered for effective conservation of the total genetic variation. As in China, more families should be included for those superior provenances and high variation provenances of C. equisetifolia when considering ex situ conservation, however the Dongshan, Fujian provenance could be much less for it may not be a good base to be conserved and used in improvement programs.

\section{Acknowledgements}

We thank Dr. J. M. Xu, B. S. Zeng, D. P. Xu for the good advices in this study. Dr. S. M. GAN, Q. J. HuAnG, 
D. Q. ZHANG, J. Zeng are thanked for their kind help in the laboratory. Ms. X. H. ZHANG prepared the primers for this study. This trial is part of the 863 program (2002AA241091) supported by the Ministry of Science and Technology of the People's Republic of China, and supported by the national '11th five-year plan' forestry program_2006BAD01A1605_, also supported by the fund of native science of Guangdong province (06024658).

\section{References}

BARRETt, B. A. and K. K. KIDwEEL (1998): AFLP-based genetics diversity assessment among wheat cultivars from the pacific northwest. Crop Science 38: 1261-1271.

Brown, A. H. D., M. T. ClegG, A. L. KAHLer and B. S. WEIR (1990): Plant population genetics, breeding, and genetic resources. Sinauer Associates, Sunderland/MA.

Cardoso, S. R. S., N. B. Eloy, J. Provan, M. A. Cardoso and P. C. G. FERREIRA (2000): Genetic differentiation of Euterpe edulis Mart. Populations estimated by AFLP analysis. Mol. Ecol. 9: 1753-1760.

DoYLE, J. (1991): DNA protocols for plants-CTAB total DNA isolation, pp. 283-293. In: Molecular Techniques in Taxonomy, edited by HewitT, G. M., A. Johnston, Springer, Berlin.

EREN Kandedmir, G. I. KANDEMIR and Z. KAYA (2004): Genetic Variation in Turkish Red Pine (Pinus brutia Ten.) Seed Stands as Determined by RAPD Markers. Silvae Genetica 53(4-5): 169-175.

HAMRICK, J. L. and M. J. W. GoDT (1990): Allozyme diversity in plant species, pp. 43-63. In: Plant population genetics, breeding, and genetic resources, edited by A. H. D. Brown, M. T. ClegG, A. L. Kahler and B. S. WEIR, Sinauer Associates, Sunderland/MA.

Ho, K. Y., C. H. OU, J. C. YANG and J. Y. Hsiao (2000): An assessment of DNA polymorphisms and genetic relationships of Casuarina equisetifolia using RAPD markers. Bot. Bull. Acad. Sin. 43: 93-98.

Hong, Y. P., H. Y. Kwon, K. S. KIM, K. N. Hong and Y. Y. KIM (2004): Discordance Between Geographical Distribution and Genetic Relationship Among Populations of Japanese Red Pine in Korea Revealed by Analysis of I-SSR Markers. Silvae Genetica 53(3): 89-92.

JANssen, P., R. Coopman and Y. S. G. Hu (1996): Evaluation of the DNA fingerprinting method AFLP as a tool in bacterial taxonomy. Microbiology 142: 1881-1893.

Jones, C. J., K. J. Edwards and S. CASTIGLione (1998): Reproducibility testing of AFLPs by a network of European laboratories, pp. 191-192. In: Molecular tools for screening biodiversity, edited by A. KARP, P. G. ISAAC, D. S. Ingram, Chapman and Hall, London.

LI, F. G. and N. H. XIA (2005): Population structure and genetic diversity of an endangered species, Glyptostrobus pensilis (Cupressaceae). Bot. Bull. Acad. Sin. 46: $155-162$.

Lewontin, R. C. (1972): The apportionment of human diversity. Evol. Biol. 6: 381-398.

Shrestha, M. K., H. Volkaert and D. V. Straeten (2005): Assessment of genetic diversity in Tectona grandis using amplified fragment length polymorphism markers. Canadian Journal of Forest Research 35: 1017-1022.

Mantel, N. (1967): The detection of disease clustering and a generalized regression approach. Cancer Research 27: 209-220.
McDermott, J. M. and B. A. McDonald (1993): Gene flow in plant photosystems. Annual Review of Phytopathology 31: 353-373.

Midgley, S. J., J. W. Turnbull and R. D. Johnston (1983): Casuarina Ecology, Management and Utilization, Proceedings of an international workshop, Canberra, Australia.

MilleR, M. P. (1998): AMOVA-PREP 1.01: A program for the preparation of AMOVA input files from dominantmarkers raw data. Computer Software Distributed by the Author.

Ming, J. and W. C. GU (2006): Genetic Diversity in Natural Populations of Syringa oblata Detected by AFLP Markers. Acta Horticulturae Sinica 33(6), 1269-1274.

Muluvi, G. M., J. I. Sprent, N. Soranzo, J. Provan, D. Odee and G. FolKard et al. (1999): Amplified Fragment length polymorphism (AFLP) analysis of genetic variation in Moringa oleifera Lam. Mol. Ecol. 8: 463-470.

NEI, M. (1973): Analysis of gene diversity in subdivided populations. Proceedings of the National Academy of Sciences of the United States of America 70: 3321-3323.

NEI, M. (1978): Estimation of average heterozygosity and genetic distance from a small number of individuals. Genetics 89, 583-590.

Pinyopusarerk, K. and E. R. Williams (2000): Rangewide provenance variation in growth and morphological characteristics of Casuarina equisetifolia grown in Northern Australia. Forest Ecology and Management 134, 219-232.

Pinyopusarerk, K. and A. P. N. House (1993): Casuarina: an annotated bibliography. International Centre for Research in Agroforestry, Nairobi.

RohlF, F. J. (1994): NTSYS-PC, Numerical Taxonomy and Multivariate. Analysis System 1.80 Exeter Software, New York..

Shrestha, M. K., H. Volkaert and D. V. D. Straeten (2005): Assessment of genetic diversity in Tectona grandis using amplified fragment length polymorphism markers. Canadian Journal of Forest Research 35: 1017-1022.

Stefenon, V. M., O. Gailing and R. Finkeldey (2006): Phylogenetic Relationship Within Genus Araucaria (Araucariaceae) Assessed by Means of AFLP Fingerprints. Silvae Genetica 55(2): 45-52.

Stewart, C. N. and L. Excoffier (1996): Assessing population genetic structure and variability with RAPD data: application to Vaccinium macrocarpon (American Cranberry). Journal of Evolution Biology 9: 153-171.

StreifF, R., T. LabBe, R. Bacilieri, H. Steinkellner, J. Glossl and A. Kremer (1998): Within population genetic structure in Quercus robur L. and Quercus petraea (Matt.) Liebl. assessed with isozymes and microsatellites. Molecular Ecology 7: 317-328.

Vos, P., R. Hogers and M. BLEEKER (1995): AFLP: a new technique for fingerprinting. Nucleic Acids Research 23(21): 4407-4414.

Wilson, K. D. and L. A. S. Johnson (1989): Casuarinaceae, Flora of Australia, vol. 3, Australian Government Publishing Service, Canberra.

Wright, S. (1969): Evolution and Genetics of Populations: The Theory of Gene Frequencies. Chicago: Univ. Chicago Press.

Xue, X., Y. Wang, H. Korpelainen and C. Li (2005): Assessment of AFLP-Based Genetic Variation in the Populations of Picea asperata. Silvae Genetica 54(1): $24-30$. 
YANG, J. C., T. Y. Chang, T. H. Chen and Z. Z. Chen (1995): Provenance trial of Casuarina equisetifolia in Taiwan. 1. Seed weight and seedling growth. Bull. Taiwan For. Res. Inst. New Series 10: 170-195.

YeH, F. C., R. C. YANG and T. Boyle (1999): POPGENE version 1.31. Microsoft Windows-based freeware for population genetic analysis. University of Alberta, Edmonton
ZenG, J., Y. P. ZoU, J. Y. BAI and H. S. Zheng (2003): RAPD analysis of genetic variation in natural populations of Betula alnoides from Guangxi, China. Euphytica 134: 33-41.

Zhong, C. L., C. J. Shi and W. H. WANG (2001): Provenance Trials of Casuarina equisetifolia in Southern China. Forest Research 14(4): 408-415.

\title{
Annual Fertility Variation in Clonal Seed Orchards of Teak (Tectona grandis L.f.) and its Impact on Seed Crop
}

\author{
By A. Nicodemus ${ }^{1), *)}$, M. VARGhese ${ }^{1)}$, B. NAGARAJAN ${ }^{1)}$ and D. LindGren ${ }^{2)}$ \\ (Received 15 ${ }^{\text {th }}$ March 2008)
}

\begin{abstract}
Fertility variation was studied in two clonal seed orchards (CSO) of teak in four consecutive years (2003-2006). Both orchards were raised in 1976 with grafts of phenotypes selected for growth and form. The seed orchards of CSO I (Topslip, Tamil Nadu State) and CSO II (Walayar, Kerala State) have 15 and 20 clones, respectively, with 13 common clones. The proportion of flowering ramets was generally low ranging from 16 to $53 \%$ across years. The best fruit yield during the study period was around $18 \mathrm{~kg} \mathrm{ha}^{-1}$ in CSO I and $17 \mathrm{~kg} \mathrm{ha}^{-1}$ in CSO II. Highly significant clonal variation and clone by year and clone by site interactions were observed for fertility traits. The clonal contribution was more skewed in poor flowering years than in abundant flowering years and in CSO II than in CSO I. Broad sense heritability for flower and fruit production per tree was low to moderate $(0.16$ to 0.55$)$. Flower and fruit production by individual ramets in successive years were positively correlated. Correlations between reproductive and growth traits were generally low, but correlation was strong between flowering and fruiting. Fertility variation and group coancestry were higher in poor flowering years than in abundant years and in CSO II than CSO I. Restricting seed collection to abundant flowering years,
\end{abstract}

\footnotetext{
1) Institute of Forest Genetics and Tree Breeding, PB 1061, Coimbatore 641 002, Tamil Nadu. India.

2) Department of Forest Genetics and Plant Physiology, Swedish University of Agricultural Sciences, SE-901 83 Umeå, Sweden.

*) Corresponding author: Institute of Forest Genetics and Tree Breeding, PB 1061, Coimbatore 641 002, Tamil Nadu. India. Phone: +91-422-2431540. Fax: +91-422-430549. E-mail: nico@ icfre.org
}

adjusting ramet number to balance contribution of clones and mixing of seeds from successive years are suggested to reduce relatedness among orchard progeny. The usefulness of low input breeding options for teak like seed production areas are also discussed.

Key words: Flowering, fruit production, diversity, coancestry, heritability, status number.

\section{Introduction}

Teak (Tectona grandis L.f.) is a high value tropical species acclaimed world over for its timber quality. Increased demand for timber and restrictions on felling from natural forests has prompted large scale planting of teak throughout the tropics (PANDEY and BROWN, 2000). Large quantities of seed are required every year to establish new plantations. Clonal seed orchards (CSO) were planted in India and other countries for domesticating and breeding teak and produce genetically improved seed. The first seed orchard was established in India during 1962 and since then more than 1000 ha of CSOs have been planted in different parts of the country (KEDHARNATH and MATTHEWS, 1962; KATWAL, 2005). Seed production and germination has been generally low in most of these orchards (INDIRA and BASHA, 1999; KJÆR et al., 1999; MATHEW and VASUdEVA, 2003). As a result, seed requirement for new plantations is met from seed production areas and existing plantations. Teak breeding programmes have not moved beyond the first generation clonal orchards.

Low seed production in teak orchards has prompted many studies on the reproductive behaviour of teak dur- 